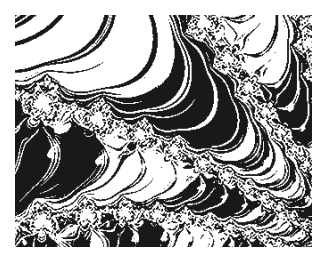

https://doi.org/10.5559/di.29.4.02

\title{
STUDENTS' ATTITUDES \\ TOWARD THE APPLICATION \\ OF MOBILE AUGMENTED \\ REALITY IN HIGHER \\ EDUCATION
}

Ivan STOJŠIĆ, Anđelija IVKOV-DŽIGURSKI

University of Novi Sad, Faculty of Sciences, Novi Sad, Serbia

Olia MARIČIĆ

University of Novi Sad, Faculty of Education in Sombor,

Sombor, Serbia

Jelena STANISAVLJEVIĆ

University of Belgrade, Faculty of Biology, Belgrade, Serbia

Jelena MILANKOVIĆ JOVANOV, Tamara VIŠNIĆ

University of Novi Sad, Faculty of Sciences, Novi Sad, Serbia

UDK: $378.018 .43: 004$

316.644-057.875:004

Prethodno priopćenje

Primljeno: 20. 12. 2018.

Acknowledgment

This research was supported by the Project No. 114-451-2465/ 2018-02 (Funded by the Provincial Secretariat for Higher Education and Science, Autonomous Province of Vojvodina, Republic of Serbia).
Virtual (VR) and augmented reality (AR) have emerged from the framework of academic and industrial laboratories and have acquired global attention. Currently, the focus shifted from the technologies themselves to finding adequate teaching and learning applications. In this paper, the students' attitudes toward the application of mobile AR (MAR) in higher education (HE) were researched (with a focus on augmented textbooks). The results showed that the students have a mostly positive attitude, and it is concluded that there was no statistically significant difference between the STEM (science, technology, engineering, and mathematics) and non-STEM students' opinions regarding this topic. Based on the results, the further research and integration of this technology into HE settings can be suggested.

Keywords: augmented reality, augmented textbook, higher education, students' attitudes

Ivan Stojšić, University of Novi Sad, Faculty of Sciences, Department of Geography, Tourism and Hotel Management, Trg Dositeja Obradovića 3, 21000 Novi Sad, Republic of Serbia. 
The development of new technologies is often accompanied by attempts to introduce them into an educational setting (Billinghurst et al., 2015). A rapid social adaptation to smartphones followed with the recent innovations in the field of immersive technologies enabled the access to VR and AR to almost everyone (Martín-Gutiérrez et al., 2017). Besides advertising and shopping, entertainment and gaming, and military and medical applications, numerous papers (see Billinghurst et al., 2015; Carmigniani et al., 2011; Cheng \& Tsai, 2013; Daniela \& Lytras, 2019; Lee, 2012; Martín-Gutiérrez et al., 2017; Núñez et al., 2008; Yuen et al., 2011) suggested that education is one of the most promising areas for AR implementation, recognizing the potential of this technology to improve teaching and learning at all levels of education.

Yuen et al. (2011) defined AR as a spectrum of technologies that project different types of computer-generated materials into the user's perception of the real world. In the reality-virtuality continuum (between the real and the fully virtual environment), AR is a part of mixed reality (MR) together with augmented virtuality (Milgram \& Kishino, 1994). Nowdays, AR is often presented as a segment of cross reality (or $\mathrm{XR}$ ), which enables applications (apps) to be developed and run on different platforms and various AR, VR, and MR devices (Seo et al., 2018).

In educational settings, AR may aid the presentation of abstract $3 \mathrm{D}$ concepts and help simulate dynamic processes that are not available or visible to students in real life, as well as improve teaching of spatially complex topics (Dünser et al., 2012). Lee (2012) indicated that AR is a very efficient technology for HE institutions and particularly useful for improving students' knowledge and skills, especially on complex theories or mechanisms of systems or machinery.

This study's main focus is to analyze the application of MAR in HE (mostly with augmented textbooks) and students' attitudes toward this educational technology. The remaining sections of this paper are arranged as follows. Previous studies and the concept of augmented books are presented in the next section, followed by the description of the research aim and research questions. The Method section tells the details of participants and the instrument and procedure used in gathering the data. In the Results section, we reported findings of analyzing both quantitative and qualitative data. The Discussion section shows a reflection on results and a comparison with previous research. Conclusions are presented in the last section. 
Several meta-analyses (see Akçayır \& Akçayır, 2017; Bacca et al., 2014; Chen et al., 2017; Garzón \& Acevedo, 2019) reported that AR has been significantly researched in HE settings (mostly at the bachelor level). The most recent one (Garzón \& Acevedo, 2019) showed that AR has a medium size effect on students' learning gains $(d=0.68)$ and that this technology is more efficient compared to traditional lecture-based teaching or multimedia use. However, the way that AR educational content is designed, implemented in the teaching process, and used for learning is particularly important (Wu et al., 2013). The starting point for creating useful AR apps and content should be the curriculum, the pedagogical foundation and specific teaching and learning activities (Radu, 2014), but user interface and experience is a key factor for engagement (Chatzopoulos et al., 2017). Also, AR should enhance the traditional teaching materials, not replace them (Billinghurst \& Dünser, 2012).

Yuen et al. (2011) emphasized five significant groups of AR application in education: (a) AR books, (b) AR gaming, (c) discovery-based learning, (d) objects modeling, and (e) skills training. Similarly, Billinghurst and Dünser (2012) indicated augmented books and AR apps for handheld mobile devices to be the two leading formats for using AR in learning and teaching processes.

One of the first publications in the area of AR books is the work of Billinghurst et al. (2001) where the authors presented the prototype of "The MagicBook". In the past years, various names for the AR books emerged in the literature, such as: augmented books, MagicBook, AR multimedia books, digilog books, and virtual 3D pop-up books (Lim \& Park, 2011). Altinpulluk and Kesim (2016) analyzed 46 studies (published in the period of 1993-2013) where the AR technology was used with books and suggested their classification as: (a) AR book, (b) augmented desk/paper augmentation approach, (c) 3D pop-up book, (d) tangible AR approach, and (e) MR book. The same authors pointed out that the AR books (in the selected studies) used different technologies (such as head-mounted displays [HMDs] and computers, but the newer ones used predominantly mobile devices).

The AR books present a significant segment of AR application in education since this technology enables adding virtual digital content to the printed textbook pages (Dünser et al., 2012). In that manner, the users (students) can simultaneously use and integrate the advantages of both real (physicality, robustness, and transportability) and digital (multimedia and multisensory feedback information) books (Grasset et al., 
DRUŠ. ISTRAŽ. ZAGREB GOD. 29 (2020), BR. 4, STR. 535-554

STOJŠIĆ, I. ET AL.: STUDENTS' ATTITÜDES...
2008; Ha et al., 2011). In other words, with AR a gap between physical objects and virtual information (and between on and offline learning materials) can be merged while keeping the strengths of each (Bujak et al., 2013; Delello et al., 2015). Grasset et al. (2008) emphasized that the augmented content in books typically includes: (a) 2D static content (such as images, schemes, and text), (b) 2D dynamic content (such as video materials and animations), (c) 3D content (such as static 3D objects and dynamic models, animations, avatars, and similar), and (d) sound (ambient, spatial, and interactive).

Based on the analysis of research studies, Lim and Park (2011) emphasized that the AR textbooks have a positive influence on learning outcomes since they improve the understanding of what was read, as well as on memory, concentration, interactivity, imagination, and problem-solving skills. The experimental studies using the AR textbooks at university/college level were mostly done in the STEM fields (see Ferrer-Torregrosa et al., 2015; Küçük et al., 2016; Martín-Gutiérrez et al., 2010; Roca-González et al., 2017; Turan et al., 2018).

By using and developing educational MAR apps, a unique and individualized learning experience can be provided to students on their own devices (Frank et al., 2016). According to O'Shea et al. (2009), AR could reach its full potential in education by leveraging student-owned technologies such as smartphones (nowadays this concept is known as "bring your own device" - BYOD). Common features and sensors (such as a GPS receiver, gyroscope, and accelerometer) built-in current mobile devices are sufficient to support the MAR technology (Mota et al., 2018). Through the use of smartphones, MAR can provide the students with a new approach to educational contents, making a learning environment always available (regardless of place and time), which is particularly important in HE (Jamali et al., 2015). Chatzopoulos et al. (2017) stated that "the use of books and notebooks with MAR systems can lead to a better learning process" (p. 6922). However, before considering the integration of MAR apps, learners' opinions must be examined first (Akçayır \& Akçayır, 2017), since the success of a new educational technology depends on how well students perceived the usefulness of such technology (Rasimah et al., 2011).

According to Seraji et al. (2017), studies dealing with the attitudes toward different educational technologies are not something new, but they are significant since attitudes can influence the acceptance and actual use. Previous studies (see Andújar et al., 2011; Chang et al., 2015; Delello et al., 2015; Ibáñez et al., 2016; Küçük et al., 2016; Martín-Gutiérrez et al., 2010; Núñez et al., 2008; Rasimah et al., 2011) used short question- 
DRUŠ. ISTRAŽ. ZAGREB GOD. 29 (2020), BR. 4, STR. 535-554

STOJŠIĆ I. ET AL: STUDENTS' ATTITUDES... naires, surveys based on an enhanced version of the Technology Acceptance Model (TAM; Davis et al., 1989) or qualitative feedback, and reported that the HE level students usually have positive attitudes towards the educational use of AR. However, we did not find larger or country-related studies that deal with determining students' attitudes toward MAR.

\section{PURPOSE AND RESEARCH QUESTIONS}

Taking into account the potential affordances of MAR apps and previous research, we started with the assumption that a significant number of HE students are probably, at least in an elementary way, familiar with this technology (primarily through largely popular mobile apps [such as Pokémon Go] and via augmented filters that are available in certain social network apps [for example, Snapchat]).

The aim of this research was to determine students' attitudes toward the application of MAR in HE institutions in the Republic of Serbia. Along the line with the aim, six research questions emerged:

1. What is the students' attitude about the application of AR in HE?

2. Does previous knowledge about AR affect the students' attitude?

3. Does previous use of MAR have an influence on the students' attitude?

4. Does the study program (STEM or non-STEM) have an influence on the students' attitude about the application of AR in HE?

5. Would the students be willing to use augmented textbooks if they were available?

6. What is the students' opinion on the utility of adding augmented digital content into the textbooks and other teaching/learning materials?

\section{METHOD}

\section{Sample and participants}

In this study a voluntary sampling method was used, which is common for online surveys in education-related research (see Livas et al., 2019; Ray et al., 2019). The participants were students who were enrolled in HE institutions in the Republic of Serbia. A total of 215 usable responses were received (seven responses were unreliable and excluded). Figure 1 presents the students in regard to the HE institutions they attended.

The age of participants ranged from 18 to 46, and the mean age was 23.51 years $(S D=4.19)$. The gender structure was dominated by female participants $(74.9 \%)$. The highest number, 
DRUŠ. ISTRAŽ. ZAGREB GOD. 29 (2020), BR. 4, STR. 535-554

STOJŠIĆ, I. ET AL.:

The students according to the university/schoo in which they were enrolled STUDENTS' ATTITUDDES..

? FIGURE 1

with a total of $164(73.3 \%)$, were bachelor level students, 35 $(16.3 \%)$ were master students, while $16(7.4 \%)$ were $\mathrm{PhD}$ students. Ninety-three $(43.3 \%)$ students were attending STEM study programs, and $122(56.7 \%)$ students were attending non-STEM study programs.

$\begin{array}{cc}\text { University of Belgrade } & 71 \\ \text { University of Novi Sad } & 58 \\ \text { University of Niš } & 35 \\ \text { University of Kragujevac } \square & 15 \\ \text { University of Priština temporarily } \\ \text { settled in Kosovska Mitrovica } \\ \text { University of Arts in Belgrade } \square \\ \text { Private universities } \\ \text { (Megatrend and Singidunum) } \\ \text { Higher education vocational } \\ \text { schools (both state and private) }\end{array}$

An online questionnaire was created for the purpose of this research.

The first part of the questionnaire included an informative text that explained the notion of $A R$ and the various possibilities of the application of this technology in HE. Examples of the AR textbooks were presented through an embedded video.

The second part contained questions about the students' demographics and school information (e.g., gender, age, name of the HE institution and study program, etc.), their ownership and usage of mobile devices, as well as two questions regarding their previous knowledge and experience with the MAR technology (ranging from 1 - none to $4-$ high).

The third part included a five-point Likert-type scale (ranging from 1 - strongly disagree to 5 - strongly agree). In constructing this small scale to measure the students' attitude about the application of AR in HE, we started with several items from the Augmented Reality Applications Attitude Scale (ARAAS; Küçük et al., 2014). The ARAAS (Küçük et al., 2014) consists of 15 items, which measures three factors: (a) use satisfaction, (b) use anxiety, and (c) use willingness. Through the authors' discussion the selected items were highly modified to reflect our research context and goal. Our final scale contained seven items, which were defined both as positive and negative statements. A reverse scoring method was used for the negative statements, and the fitness of sample has been checked for an 
DRUŠ. ISTRAŽ. ZAGREB GOD. 29 (2020), BR. 4, STR. 535-554

STOJŠIĆ, I. ET AL:

STUDENTS' ATTITUDES... value was 0.795, and the results of Bartlett's test of sphericity $\left(\chi^{2}=552.66, p<0.001\right)$ suggested that performing factor analysis was suitable (Coakes, 2012). The principal component analysis with Promax rotation method was performed. As a result, seven items have been categorized under two factors accounting for $67.6 \%$ of the variance in the attitude toward the application of AR in HE (Table 1).

Items

$M S D$ Factor 1 Factor 2 -total correlation

1. Augmented reality is a useful tool when it comes to visualization of objects, phenomena, and processes (that are not easily available for direct observation).

$3.95 \quad 1.04 \quad 0.801$

0.668

3. Augmented reality enables a higher interaction with educational contents.

$\begin{array}{lll}4.00 & 0.95 & 0.867\end{array}$

5. The learning process can be facilitated by adding AR content (such as interactive 3D models animations, and video materials) into textbooks and other teaching materials.

0.778

7. The technology of augmented reality can be successfully integrated into traditional teaching and learning means.

$\begin{array}{lll}3.92 & 1.04 & 0.839\end{array}$

2. There are no real benefits in using the technology of augmented reality in higher education.

4. Augmented reality should be used only for entertainment purposes (not in higher education).

6. The integration of augmented reality in higher educational settings is unnecessary (currently used tools are efficient and sufficient).

Explained total variance (\%)

$44.49 \quad 23.13$

Note: Mean and standard deviation values were not reversed for the negative items. Also, only loadings $>0.30$ are displayed.

( TABLE 1

The principal component analysis with Promax rotation (Pattern matrix) and the corrected item-total correlation
The first factor was named "perceived usability" (PU) and consisted of four positive statements. The second factor was named "perceived use anxiety" (PUA) and consisted of three negative statements. There was a weak $(r=-0.21, p=0.002)$, but a statistically significant negative correlation between the two factors. The internal consistency of factors measured with Cronbach's alpha coefficient were 0.87 and 0.66 , respectively. Cronbach's alpha coefficient for the whole scale (with reverse 
DRUŠ. ISTRAŽ. ZAGREB GOD. 29 (2020), BR. 4, STR. 535-554

STOJŠIĆ, I. ET AL.: STUDENTS' ATTITUDES... scoring for negative items) was 0.77 , which indicates a satisfactory reliability (Loewenthal, 2001; Nunnally, 1978). Also, the corrected item-total correlation ranged from 0.231 to 0.677 , which suggests that all items measure the same trait.

The final part of the questionnaire contained several open-ended questions, such as: "How do you see the possible application of AR in higher education?", "Would you use augmented textbooks if they were available?", and "Would the textbooks and other teaching/learning materials (covered by your study program) be enhanced with using MAR?"

\section{Data collection and analysis}

The research was conducted at the end of the first term of the 2016-2017 school year. A link directed to the survey page was available on many official university/college webpages and student Facebook groups in the Republic of Serbia. The participation was voluntary and the students were not compensated. The students were informed that by filling out the questionnaire they provide informed consent to the use of their data for the research purposes. Quantitative and qualitative data were collected.

Statistical analyses of quantitative data were performed using IBM SPSS Statistics (version 21) software. Besides descriptive statistics, non-parametric tests (Kruskal-Wallis $H$ and Mann-Whitney $U$ ) were used for answering the second, third, and fourth research question since there was a significant difference in the size of the groups, and the dependent variable (attitude toward the application of AR in HE) deviated from the normal distribution (Shapiro-Wilk test $=0.976, p=0.001$, $N=215)$. For the fifth and sixth research question, the Pearson's chi-square test was applied to test the potential difference between the STEM and non-STEM students' answers.

An inductive thematic analysis was used to interpret the students' answers from open-ended questions (see Braun \& Clarke, 2006; Fereday \& Muir-Cochrane, 2006). The first and the third author found related segments in participants' answers and grouped them as themes using Microsoft Excel. The final list of themes emerged through discussion between the two authors (who performed the analysis). A lot of students' responses reflected more than one concept. Consequently, those answers were assigned to multiple themes.

\section{RESULTS}

The first research question analyzed how the students perceived the application of AR in HE. In sum, it can be determined that the students included in this research have a medium-positive attitude $(M=3.85, S D=0.64)$ when the results from the constructed scale (the values of the negatively defined statements were reversed) are taken into account. On aver- 
DRUŠ. ISTRAŽ. ZAGREB GOD. 29 (2020), BR. 4, STR. 535-554

STOJŠIĆ I. ET AL: STUDENTS' ATTITUDES... age, the students answered PU items with agree $(M=4.01, S D=$ $0.86)$ and the PUA items with disagree $(M=2.36, S D=0.73)$.

The thematic analysis of open-ended responses confirmed that the majority of students $(n=156)$ perceived AR positively, while 23 students $(10.7 \%)$ did not form an opinion. One hundred and twelve students also indicated specific potential benefits of MAR (87.5\% of their participants' answers were grouped in more than one category). The themes were:

(1) Better understanding $(n=95)$ - a large number of students indicated a better understanding of learning materials as a potential advantage of MAR.

(2) Facilitating the learning process $(n=86)$ - for example a female postgraduate student at the Faculty of Economics wrote: "The application of this type of technology would certainly drastically ease and improve students' learning," and a female pharmacy student stated that: "Learning with augmented animations, pictures and 3D representations in the textbooks would be simpler since digital visualization would replace many paragraphs of text which often, despite being read and comprehended, do not necessarily convey the content properly."

(3) Visualization $(n=64)$ - a substantial number of students indicated visualization as one of the potential MAR benefits. For example, a male chemistry student noted: "It is sometimes hard to understand certain topics in chemistry only based on theory, no matter how well it was explained. Visualization in chemistry is extremely important."

(4) Personalizing learning $(n=20)$ - for instance a female master level tourism student stated that: "The application of this type of learning (with demonstration and explanation) would be very efficient for me," while a female education postgraduate student wrote: "The application of augmented reality as a teaching tool is the closest to personalized and adaptive learning experiences."

(5) Increasing students' interest and motivation $(n=19)$ - several students stated that the integration of MAR would probably increase their learning motivation. For example, a female history student wrote: "This technology would show everyone that history is interesting and not just memorization of facts and data."

Few answers contained notes of possible drawbacks (such as the insufficient development of AR technology and high costs) or expressed certain concern (e.g., influence on health and potential unsuitability). Several students $(n=18)$ emphasized that this research was not suitable for the conditions students have at the HE institutions in the Republic of Serbia, as well as the economic state of the country, while 11 students had the opinion that it is too early to discuss this topic. For 
DRUŠ. ISTRAŽ. ZAGREB GOD. 29 (2020), BR. 4, STR. 535-554

STOJŠIĆ, I. ET AL.: STUDENTS' ATTITUDES... $\rightarrow$ TABLE 2

The Kruskal-Wallis $H$-test results (prior knowledge about $A R$ ) instance, a male journalism student asked: "Why are we discussing this when it will not happen at our faculty in the next 10 years?"

The second research question was related to the assumption that the previous students' knowledge about AR has an influence on their attitude toward the application of this technology in HE. Based on the answers to the question on their previous level of knowledge about AR, the participants were divided into four groups. The attitude toward the application of AR in HE was measured on the five-point scale with seven items (the values of the negatively defined statements were reversed). A higher mean value reflects a more positive attitude. The results of the Kruskal-Wallis $H$-test (Table 2) were statistically significant $\chi^{2}(3, N=215)=16.40, p=0.001$. The effect size indicator eta squared $\left(\eta^{2}\right)$, could be calculated out of the Kruskal-Wallis $\chi^{2}$ value (Green \& Salkind, 2014). The calculated value $\eta^{2}=0.08$ presents a moderate effect size and shows that the $8 \%$ of variance in the attitude about the application of AR in HE can be explained by students' different prior knowledge about this technology. A post hoc analysis was conducted using the Mann-Whitney U-test (with Bonferroni correction) to examine between which groups the statistically significant difference occurred. The test results showed that the statistically significant difference existed between the first and the fourth group $(U=561.50, Z=-3.491, p<0.001, r=-0.344)$ and between the second and the fourth group $(U=390.50, Z=$ $-3.045, p=0.002, r=-0.347)$. The results suggested that those students who had high prior knowledge had a more positive attitude about the application of AR in HE than the students who were low/not familiar with this technology.

\begin{tabular}{lrrrrr}
\hline $\begin{array}{l}\text { Levels of students' prior } \\
\text { knowledge about AR }\end{array}$ & $n$ & Median & M rank & $\begin{array}{c}\text { Kruskal- } \\
\text {-Wallis } \chi^{2}\end{array}$ & $p$ \\
\hline None & 76 & 3.71 & 92.66 & 16.40 & 0.001 \\
Low & 50 & 3.71 & 99.91 & & \\
Medium & 62 & 4.14 & 117.28 & & \\
High & 27 & 4.29 & 144.85 & & \\
\hline
\end{tabular}

The third research question was related to the assumption that the level of students' prior use of MAR has an influence on their attitude about the application of this technology in HE. The results of the Kruskal-Wallis H-test (Table 3) were statistically significant $\chi^{2}(3, N=215)=10.32, p=0.016, \eta^{2}=0.05$. The post hoc analysis (Mann-Whitney $U$-test with Bonferroni correction) showed that the statistically significant difference existed between the first and the second group $(U=2277.00$, $Z=-3.085, p=0.002, r=-0.242)$, meaning that those students 
DRUŠ. ISTRAŽ. ZAGREB GOD. 29 (2020), BR. 4, STR. 535-554

STOJŠIĆ, I. ET AL.:

STUDENTS' ATTITUDES...

○ TABLE 3

The Kruskal-Wallis $H$-test results (prior use of MAR apps)

- TABLE 4 The Mann-Whitney U-test results (study program) with some prior personal experience with MAR had a more positive attitude about the application of AR in HE than the students who did not have any prior use of this technology.

\begin{tabular}{lrrrrr}
\hline $\begin{array}{l}\text { Levels of students' } \\
\text { prior use of MAR apps }\end{array}$ & $n$ & Median & M rank & $\begin{array}{c}\text { Kruskal- } \\
\text {-Wallis } \chi^{2}\end{array}$ & $p$ \\
\hline None & 98 & 3.71 & 93.88 & 10.32 & 0.016 \\
Some & 65 & 4.14 & 124.91 & & \\
Medium & 30 & 4.07 & 114.48 & & \\
High & 22 & 3.93 & 112.09 & & \\
\hline
\end{tabular}

The fourth research question was related to the assumption that the students' study program (STEM or non-STEM) has an influence on their attitude toward the application of this technology in HE. The results of the Mann-Whitney $U$-test (Table 4) were statistically insignificant, suggesting that attending the STEM or non-STEM program has no influence on students' attitude about this topic.

\begin{tabular}{lrrrrrrrr}
\hline $\begin{array}{l}\text { Students' study } \\
\text { program }\end{array}$ & $n$ & Median & $M$ rank & -Whitney U & $Z$ & $p$ & $r$ \\
\hline STEM & 93 & 3.86 & 107.22 & 5600.50 & -0.161 & 0.872 & -0.011 \\
non-STEM & 122 & 3.86 & 108.59 & & & & \\
\hline
\end{tabular}

The fifth research question was about the acceptance of the augmented textbooks. The results showed that the majority of students $(79.5 \%)$ would use them (if they were available), $2.8 \%$ of students would not use augmented content in the textbooks, while $17.7 \%$ of participants were undecided. Pearson's chi-square test results were non-significant $\chi^{2}(2, N=215)=0.28$, $p=0.872$, Cramer's $V=0.036$, showing that the STEM and non-STEM students appeared to be uniform about the acceptance of the MAR integration. The undecided students emphasized several reasons (some students gave more than one) why they were uncertain whether they supported or did not support the MAR apps, which were themed as:

(1) Nonexistence of previous experience with the AR technology $(n=24)$ - a substantial number of undecided students stated that they would be able to answer the question only after they had a direct personal experience with the AR textbooks.

(2) The material reasons (textbooks/apps price) $(n=8)$ - several students stated that the integration of AR would probably increase the costs of HE textbooks.

(3) Colleagues' opinions and experiences $(n=7)$ - certain students emphasized that they would wait for the feedback from their colleagues first, while a female student of the Faculty of 
DRUŠ. ISTRAŽ. ZAGREB GOD. 29 (2020), BR. 4, STR. 535-554

STOJŠIĆ, I. ET AL.: STUDENTS' ATTITUDES...

\section{DISCUSSION}

Philosophy stated that: "If the majority would use it, I would probably blend in."

(4) The quality and availability of the augmented content $(n=5)$ - a couple of students indicated that they would make a decision based on usefulness and availability of the augmented digital materials.

The sixth research question analyzed the students' opinions on the utility of adding augmented digital content (using the MAR technology) into the textbooks and other teaching/ learning materials covered by the study program those students were attending. The majority of the students $(62.3 \%)$ pointed out that the MAR integration would have an educational value. However, $21.4 \%$ of the students stated that the AR content might be unnecessary (or inapplicable) in their textbooks and other learning materials, while $12.6 \%$ did not know how to answer, and 8 students $(3.7 \%)$ did not give any answer. The distribution of affirmative and negative answers between the STEM and non-STEM students was not statistically significant $\chi^{2}(1, N=180)=0.06, p=0.810$, Cramer's $V=0.018$.

According to the results of this research, it can be determined that the HE students have the necessary equipment to use MAR for learning (since all the participants own a smartphone). However, the obstacles need to be emphasized, as well. The use of new technology in education does not guarantee success per se (Bower et al., 2014). The technical problems (e.g., maintaining the stability of the system, or GPS error), the need for technical support in the initial phase, as well as the possibility of a cognitive overload caused by the amount of the augmented material (or the complexity of the tasks), should be all taken into consideration when designing the AR content and activities (Cheng \& Tsai, 2013). Additionally, a certain number of schools in the Republic of Serbia forbade the use of mobile devices in classrooms (or lecture halls). Carmigniani et al. (2011) emphasized that the main problem with social acceptance of mobile devices is the degree of distraction they are creating. Hence, the AR system (implemented in mobile apps) needs to be "subtle, discrete and unobtrusive" to become socially acceptable (Carmigniani et al., 2011, p. 356).

It needs to be pointed out that the students may show resistance toward the new educational technologies if they are skeptical about their usefulness and educational value (Tarhini et al., 2015). The results of this research showed that the students mostly have a positive attitude toward the application of MAR, which correlates with other studies at the HE level (see Andújar et al., 2011; Chang et al., 2015; Delello et al., 
DRUŠ. ISTRAŽ. ZAGREB GOD. 29 (2020), BR. 4, STR. 535-554

STOJŠIĆ I. ET AL: STUDENTS' ATTITUDES...

\section{CONCLUSION}

2015; Ibáñez et al., 2016; Küçük et al., 2016; Martín-Gutiérrez et al., 2010; Núñez et al., 2008; Rasimah et al., 2011).

Daniela et al. (2018) conducted a multi-dimensional survey in the field of HE and indicated that the students' attitude toward the use of different information and communication technologies for learning is influenced by their level of digital competence, and that infrastructural problems can hinder integration and the use of new educational technology in the teaching process. The results of our research are similar, since the students with higher prior knowledge had a statistically significant more positive attitude than the students who were low/not familiar with AR, as well as that the students with some prior personal experience with the MAR apps had a statistically significant more positive attitude than the students who did not have any previous use of this technology. Additionally, several students expressed their concerns about the readiness of the HE institutions in the Republic of Serbia to adopt the AR technology.

The majority of students included in our study $(79.5 \%)$ would support the use of AR textbooks, and $62.3 \%$ of them perceived the integration of MAR apps into textbooks and other teaching/learning materials as useful. However, despite the heavy use of mobile devices in students' everyday life, the use of MAR apps for learning is not widespread (Mota et al., 2018). Also, there is a limited application of the augmented textbooks in practice (Dünser et al., 2012). The lack of programming skills among teachers is a barrier to their engagement in development and customization of the educational MAR apps (Mota et al., 2018). Still, the authoring tools can be used for creating augmented scenes through the graphic interface without the need for programming (Billinghurst \& Dünser, 2012).

The AR technology no longer requires expensive and sophisticated equipment as it was the case in the past (Akçayır \& Akçayır, 2017), and has become available to the educational institutions and students as never before (Martín-Gutiérrez et al., 2017).

The technological advancement in the Republic of Serbia is low and there are many challenges in implementing new educational technology in classrooms or lecture halls (Teo et al., 2016). However, nowadays many HE institutions are looking for modern technologies and solutions to support students and to achieve digital transformation and sustainability (Daniela et al., 2018).

In this research students' attitudes toward the application of MAR in HE were determined. Our assumption regard- 
DRUŠ. ISTRAŽ. ZAGREB GOD. 29 (2020), BR. 4, STR. 535-554

STOJŠIĆ, I. ET AL.: STUDENTS' ATTITUDES... ing students' familiarity with MAR was confirmed since more than half of the students $(54.4 \%)$ have already used the MAR apps. Based on the findings, the answers to the six research questions were:

1. Students' attitudes toward the application of AR in HE were mostly positive. A significant number of students perceived this technology as potentially useful for: (a) better understanding, (b) facilitating the learning process, (c) visualization, (d) personalizing learning, and (e) increasing students' interest and motivation. However, several students expressed concerns regarding: (a) insufficient development of MAR, (b) high costs of AR technology, (c) influence on health, (d) potential unsuitability with the current infrastructural conditions at the HE institutions in the Republic of Serbia, (e) readiness and willingness of the HE institutions to adopt the AR technology, and (f) potential influence on textbook prices.

2 . The students who had high prior knowledge about AR had a statistically significant more positive attitude toward the application of AR in HE than the students who were low/not familiar with this technology.

3 . The students with some prior personal experience with MAR had a statistically significant more positive attitude than the students who did not have any previous use of this technology.

4. Attending the STEM or non-STEM program does not influence students' attitudes toward the application of AR in HE.

5 . The majority of the students $(79.5 \%)$ who participated in this research would use the AR textbooks if they were available (with no statistical difference between the STEM and non-STEM students), but there was a significant number of undecided participants $(17.7 \%)$. The undecided students' reasons (for not being sure if they support the use of augmented textbooks) were: (a) nonexistence of any previous experience, (b) textbook/app price, (c) opinions and experiences of colleagues, and (d) quality and availability of the augmented content.

6. The majority of the students $(62.3 \%)$ perceived the MAR integration into the textbooks and other teaching/learning materials as valuable and useful for improving HE. However, $21.4 \%$ of them stated that this integration might be unnecessary (or potentially inapplicable).

This study has several limitations. Firstly, the results are not necessarily generalizable to all HE students, since voluntary response bias was possible and the sample size was not that big. Secondly, the instrument used in this research was based on the self-reported design, and the students' prior knowledge and experience with MAR were not objectively measured. Finally, the analysis of the open-ended questions (qual- 
DRUŠ. ISTRAŽ. ZAGREB GOD. 29 (2020), BR. 4, STR. 535-554

STOJŠIĆ I. ET AL: STUDENTS' ATTITUDES... itative data) can be subjective and biased since the results (the themes) depend on the researcher's interpretation (Creswell, 2014).

Taking into account the potential affordances of the MAR technology and the necessity of digital transformation (which is an ongoing process in many educational systems including the Republic of Serbia), as well as the fact that the students' attitudes were mostly positive (but bearing in mind cost-effectiveness and institutional and teachers' readiness), integration of this technology into HE can be suggested. However, the questions related to the actual influence of this technology need to be investigated in future research, as well as a comparison between students' and teachers' perceptions and attitudes.

\section{REFERENCES}

Akçayır, M., \& Akçayır, G. (2017). Advantages and challenges associated with augmented reality for education: A systematic review of the literature. Educational Research Review, 20, 1-11. https://doi.org/10. 1016/j.edurev.2016.11.002

Altinpulluk, H., \& Kesim, M. (2016). The classification of augmented reality books: A literature review. In L. Gómez Chova, A. López Martínez, \& I. Candel Torres (Eds.), INTED2016 Proceedings - 10th International Technology, Education and Development Conference (pp. 4110-4118). IATED Academy. https://doi.org/10.21125/inted.2016.0200 Andújar, J. M., Mejías, A., \& Márquez, M. A. (2011). Augmented reality for the improvement of remote laboratories: An augmented remote laboratory. IEEE Transactions on Education, 54(3), 492-500. https://doi. org/10.1109/TE.2010.2085047

Bacca, J., Baldiris, S., Fabregat, R., Graf, S., \& Kinshuk (2014). Augmented reality trends in education: A systematic review of research and applications. Educational Technology \& Society, 17(4), 133-149. https://www.j-ets.net/ETS/journals/17_4/9.pdf

Billinghurst, M., Clark, A., \& Lee, G. (2015). A survey of augmented reality. Foundations and Trends ${ }^{\circledR}$ in Human-Computer Interaction, 8(2-3), 73-272. https://doi.org/10.1561/1100000049

Billinghurst, M., \& Dünser, A. (2012). Augmented reality in the classroom. Computer, 45(7), 42-49. https://doi.org/10.1109/MC.2012.111

Billinghurst, M., Kato, H., \& Poupyrev, I. (2001). The MagicBook: A transitional AR interface. Computers \& Graphics, 25(5), 745-753. https://doi.org/10.1016/S0097-8493(01)00117-0

Bower, M., Howe, C., McCredie, N., Robinson, A., \& Grover, D. (2014). Augmented reality in education - cases, places and potentials. Educational Media International, 51(1), 1-15. https://doi.org/10.1080/09523987. 2014.889400

Braun, V., \& Clarke, V. (2006). Using thematic analysis in psychology. Qualitative Research in Psychology, 3(2), 77-101. https://doi.org/10.1191/ 1478088706qp063oa

Bujak, K. R., Radu, I., Catrambone, R., Macintyre, B., Zheng, R., \& Golubski, G. (2013). A psychological perspective on augmented real- 
DRUŠ. ISTRAŽ. ZAGREB GOD. 29 (2020), BR. 4, STR. 535-554

STOJŠIĆ, I. ET AL.: STUDENTS' ATTITÜDES... ity in the mathematics classroom. Computers $\mathcal{E}$ Education, 68, 536544. https://doi.org/10.1016/j.compedu.2013.02.017

Carmigniani, J., Furht, B., Anisetti, M., Ceravolo, P., Damiani, E., \& Ivkovic, M. (2011). Augmented reality technologies, systems and applications. Multimedia Tools and Applications, 51(1), 341-377. https://doi. org/10.1007/s11042-010-0660-6

Chang, Y.-L., Hou, H.-T., Pan, C.-Y., Sung, Y.-T., \& Chang, K.-E. (2015). Apply an augmented reality in a mobile guidance to increase sense of place for heritage places. Educational Technology \& Society, 18(2), 166-178. https://www.j-ets.net/ETS/journals/18_2/13.pdf

Chatzopoulos, D., Bermejo, C., Huang, Z., \& Hui, P. (2017). Mobile augmented reality survey: From where we are to where we go. IEEE Access, 5, 6917-6950. https://doi.org/10.1109/ACCESS.2017.2698164

Chen, P., Liu, X., Cheng, W., \& Huang, R. (2017). A review of using augmented reality in education from 2011 to 2016. In E. Popescu, Kinshuk, M. K. Khribi, R. Huang, M. Jemni, N.-S. Chen, \& D. G. Sampson (Eds.), Innovations in smart learning. Lecture notes in educational technology (pp. 13-18). Springer. https://doi.org/10.1007/978-98110-2419-1_2

Cheng, K.-H., \& Tsai, C.-C. (2013). Affordances of augmented reality in science learning: Suggestions for future research. Journal of Science Education and Technology, 22(4), 449-462. https://doi.org/10.1007/s10956012-9405-9

Coakes, S. J. (2012). SPSS version 20.0 for Windows: Analysis without anguish. Wiley.

Creswell, J. W. (2014). Research design: Qualitative, quantitative, and mixed methods approaches (4th ed.). SAGE Publications.

Daniela, L., \& Lytras, M. D. (2019). Editorial: Themed issue on enhanced educational experience in virtual and augmented reality. Virtual Reality, 23, 325-327. https://doi.org/10.1007/s10055-019-00383-z

Daniela, L., Visvizi, A., Gutiérrez-Braojos, C., \& Lytras, M. D. (2018). Sustainable higher education and technology-enhanced learning (TEL). Sustainability, 10(11), Article 3883. https://doi.org/10.3390/su10113883

Davis, F. D., Bagozzi, R. P., \& Warshaw, P. R. (1989). User acceptance of computer technology: A comparison of two theoretical models. Management Science, 35(8), 982-1003. https://doi.org/10.1287/mnsc.35.8.982

Delello, J. A., McWhorter, R. R., \& Camp, K. M. (2015). Integrating augmented reality in higher education: A multidisciplinary study of student perceptions. Journal of Educational Multimedia and Hypermedia, 24(3), 209-233. https://www.learntechlib.org/primary/p/148455/

Dünser, A., Walker, L., Horner, H., \& Bentall, D. (2012). Creating interactive physics education books with augmented reality. In V. Farrell, G. Farrell, C. Chua, W. Huang, R. Vasa, \& C. Woodward (Eds.), Proceedings of the 24th Australian Computer-Human Interaction Conference OzCHI '12 (pp. 107-114). ACM. https://doi.org/10.1145/2414536.2414554

Fereday, J., \& Muir-Cochrane, E. (2006). Demonstrating rigor using thematic analysis: A hybrid approach of inductive and deductive coding and theme development. International Journal of Qualitative Methods, 5(1), 80-92. https://doi.org/10.1177/160940690600500107 
DRUŠ. ISTRAŽ. ZAGREB GOD. 29 (2020), BR. 4, STR. 535-554

STOJŠIĆ I. ET AL: STUDENTS' ATTITÜDES...
Ferrer-Torregrosa, J., Torralba, J., Jimenez, M. A., García, S., \& Barcia, J. M. (2015). ARBOOK: Development and assessment of a tool based on augmented reality for anatomy. Journal of Science Education and Technology, 24(1), 119-124. https://doi.org/10.1007/s10956-014-9526-4

Frank, J. A., Brill, A., \& Kapila, V. (2016, January 4-6). Interactive mobile interface with augmented reality for learning digital control concepts. Proceedings of the 2016 Indian Control Conference (ICC), Hyderabad, India (pp. 85-92). https://doi.org/10.1109/INDIANCC.2016.7441110

Garzón, J., \& Acevedo, J. (2019). A meta-analysis of the impact of augmented reality on students' learning effectiveness. Educational Research Review, 27, 244-260. https://doi.org/10.1016/j.edurev.2019.04.001

Grasset, R., Dünser, A., \& Billinghurst, M. (2008). The design of a mixed-reality book: Is it still a real book? In M. A. Livingston, $\mathrm{O}$. Bimber, \& H. Saito (Eds.), Proceedings of the 7th IEEE International Symposium on Mixed and Augmented Reality (pp. 99-102). IEEE. https://doi.org/10.1109/ISMAR.2008.4637333

Green, S. B., \& Salkind, N. J. (2014). Using SPSS for Windows and Macintosh: Analyzing and understanding data (7th ed.). Pearson.

Ha, T., Lee, Y., \& Woo, W. (2011). Digilog book for temple bell tolling experience based on interactive augmented reality. Virtual Reality, 15(4), 295-309. https://doi.org/10.1007/s10055-010-0164-8

Ibáñez, M.-B., Di Serio, Á., Villarán, D., \& Delgado-Kloos, C. (2016). The acceptance of learning augmented reality environments: A case study. In J. M. Spector, C.-C. Tsai, D. G. Sampson, Kinshuk, R. Huang, N.-S. Chen, \& P. Resta (Eds.), Proceedings of the IEEE 16th International Conference on Advanced Learning Technologies - ICALT 2016 (pp. 307-311). IEEE Computer Society. https://doi.org/10.1109/ICALT.2016.124

Jamali, S. S., Shiratuddin, M. F., Wong, K. W., \& Oskam, C. L. (2015). Utilizing mobile-augmented reality for learning human anatomy. Procedia - Social and Behavioral Sciences, 197, 659-668. https://doi.org/10. 1016/j.sbspro.2015.07.054

Küçük, S., Kapakin, S., \& Göktaş, Y. (2016). Learning anatomy via mobile augmented reality: Effects on achievement and cognitive load. Anatomical Sciences Education, 9(5), 411-421. https://doi.org/10.1002/ase.1603

Küçük, S., Yılmaz, R. M., Baydaş, Ö., \& Göktaş, Y. (2014). Augmented Reality Applications Attitude Scale in secondary schools: Validity and reliability study. Eğitim ve Bilim [Education and Science], 39(176), 383-392. https://doi.org/10.15390/EB.2014.3590

Lee, K. (2012). Augmented reality in education and training. TechTrends, 56(2), 13-21. https://doi.org/10.1007/s11528-012-0559-3

Lim, C., \& Park, T. (2011). Exploring the educational use of an augmented reality books. In M. Simonson (Ed.), Proceedings of the 34th Annual Convention of the Association for Educational Communications and Technology - Jacksonville (Vol. 1 \& 2, pp. 172-182). Nova Southeastern University. https://pdfs.semanticscholar.org/8c8a/7f6c0481d38cfe1d0 da383c16f70cb95a36f.pdf

Livas, C., Katsanakis, I., \& Vayia, E. (2019). Perceived impact of BYOD initiatives on post-secondary students' learning, behaviour and wellbeing: The perspective of educators in Greece. Education and Information Technologies, 24(1), 489-508. https://doi.org/10.1007/s10639018-9791-6 
DRUŠ. ISTRAŽ. ZAGREB GOD. 29 (2020), BR. 4, STR. 535-554

STOJŠIĆ, I. ET AL.: STUDENTS' ATTITUDES...
Loewenthal, K. M. (2001). An introduction to psychological tests and scales (2nd ed.). Psychology Press.

Martín-Gutiérrez, J., Mora, C. E., Añorbe-Díaz, B., \& González-Marrero, A. (2017). Virtual technologies trends in education. Eurasia Journal of Mathematics, Science and Technology Education, 13(2), 469-486. https://doi.org/10.12973/eurasia.2017.00626a

Martín-Gutiérrez, J., Saorín, J. L., Contero, M., Alcañiz, M., Pérez-López, D. C., \& Ortega, M. (2010). Design and validation of an augmented book for spatial abilities development in engineering students. Computers \& Graphics, 34(1), 77-91. https://doi.org/10.1016/j. cag.2009.11.003

Milgram, P., \& Kishino, F. (1994). A taxonomy of mixed reality visual displays. IEICE Transactions on Information and Systems, E77-D(12), 1321-1329. https://www.researchgate.net/publication/231514051_A_ Taxonomy_of_Mixed_Reality_Visual_Displays

Mota, J. M., Ruiz-Rube, I., Dodero, J. M., \& Arnedillo-Sánchez, I. (2018). Augmented reality mobile app development for all. Computers and Electrical Engineering, 65, 250-260. https://doi.org/10.1016/j.compeleceng.2017.08.025

Núñez, M., Quirós, R., Núñez, I., Carda, J. B., \& Camahort, E. (2008). Collaborative augmented reality for inorganic chemistry education. In J. Lloret Mauri, A. Zaharim, A. Kolyshkin, M. Hatziprokopiou, A. Lazakidou, M. Kalogiannakis, K. Siassiakos, \& N. Bardis (Eds.), Proceedings of the 5th WSEAS/IASME International Conference on Engineering Education (EE' 08) (pp. 271-277). World Scientific and Engineering Academy and Society (WSEAS). http://www.wseas.us/e-library/conferences/2008/crete/education/education43.pdf

Nunnally, J. C. (1978). Psychometric theory (2nd ed.). McGraw-Hill.

O'Shea, P., Mitchell, R., Johnston, C., \& Dede, C. (2009). Lessons learned about designing augmented realities. International Journal of Gaming and Computer-Mediated Simulations (IJGCMS), 1(1), 1-15. https://doi. org/10.4018/jgcms.2009010101

Radu, I. (2014). Augmented reality in education: A meta-review and cross-media analysis. Personal and Ubiquitous Computing, 18(6), 1533 1543. https://doi.org/10.1007/s00779-013-0747-y

Rasimah, C. M. Y., Ahmad, A., \& Zaman, H. B. (2011). Evaluation of user acceptance of mixed reality technology. Australasian Journal of Educational Technology, 27(8), 1369-1387. https://doi.org/10.14742/ajet.899

Ray, E. C., Arpan, L., Oehme, K., Perko, A., \& Clark, J. (2019). Testing restorative narratives in a college student resilience project. Innovative Higher Education, 44(4), 267-282. https://doi.org/10.1007/s10755019-9464-4

Roca-González, C., Martin-Gutierrez, J., García-Dominguez, M., \& del Carmen Mato Carrodeguas, M. (2017). Virtual technologies to develop visual-spatial ability in engineering students. Eurasia Journal of Mathematics, Science and Technology Education, 13(2), 441-468. https://doi. org/10.12973/eurasia.2017.00625a

Seo, D., Yoo, B., \& Ko, H. (2018, June 20-22). Webizing collaborative interaction space for cross reality with various human interface devices. Proceedings of 23rd International Conference on Web3D Technology (Web3D '18), Poznań, Poland (8 pages). https://doi.org/10.1145/3208806.3208808 
DRUŠ. ISTRAŽ. ZAGREB GOD. 29 (2020), BR. 4, STR. 535-554

STOJŠIĆ I. ET AL: STUDENTS' ATTITUUDES...

Seraji, N. E., Ziabari, R. S., \& Rokni, S. J. A. (2017). Teacher's attitudes towards educational technology in English language institutes. International Journal of English Linguistics, 7(2), 176-185. https://doi.org/ 10.5539/ijel.v7n2p176

Tarhini, A., Hone, K., \& Liu, X. (2015). A cross-cultural examination of the impact of social, organizational and individual factors on educational technology acceptance between British and Lebanese university students. British Journal of Educational Technology, 46(4), 739-755. https://doi.org/10.1111/bjet.12169

Teo, T., Milutinović, V., \& Zhou, M. (2016). Modelling Serbian pre-service teachers' attitudes towards computer use: A SEM and MIMIC approach. Computers $\mathcal{E}$ Education, 94, 77-88. https://doi.org/10.1016/ j.compedu.2015.10.022

Turan, Z., Meral, E., \& Sahin, I. F. (2018). The impact of mobile augmented reality in geography education: Achievements, cognitive loads and views of university students. Journal of Geography in Higher Education, 42(3), 427-441. https://doi.org/10.1080/03098265.2018.1455174

Wu, H.-K., Lee, S. W.-Y., Chang, H.-Y., \& Liang, J.-C. (2013). Current status, opportunities and challenges of augmented reality in education. Computers $\mathcal{E}$ Education, 62, 41-49. https://doi.org/10.1016/j.comp edu.2012.10.024

Yuen, S. C.-Y., Yaoyuneyong, G., \& Johnson, E. (2011). Augmented reality: An overview and five directions for AR in education. Journal of Educational Technology Development and Exchange (JETDE), 4(1), 119_ 140. https://doi.org/10.18785/jetde.0401.10

\section{Stavovi studenata prema primjeni mobilne proširene stvarnosti u visokom obrazovanju}

Ivan STOJŠIĆ, Anđelija IVKOV-DŽIGURSKI

Sveučilište u Novom Sadu, Prirodno-matematički fakultet, Novi Sad, Srbija

Olja MARIČIĆ

Sveučilište u Novom Sadu, Pedagoški fakultet u Somboru, Sombor, Srbiija

Jelena STANISAVLJEVIĆ

Sveučilište u Beogradu, Biološki fakultet, Beograd, Srbija

Jelena MILANKOVIĆ JOVANOV, Tamara VIŠNIĆ

Sveučilište u Novom Sadu, Prirodno-matematički fakultet, Novi Sad, Srbija

Virtualna i proširena stvarnost izašle su iz okvira akademskih i industrijskih laboratorija i stekle su globalnu pozornost. Trenutačno se fokus pomaknuo sa samih tehnologija prema pronalaženju odgovarajuće primjene u poučavanju i učenju. U ovom radu istraživani su stavovi studenata o primjeni mobilne proširene stvarnosti u visokom 
DRUŠ. ISTRAŽ. ZAGREB GOD. 29 (2020), BR. 4, STR. 535-554

STOJŠIĆ, I. ET AL.:

STUDENTS' ATTITUDES...
Rezultati su pokazali da studenti imaju uglavnom pozitivan stav, a zaključeno je i da ne postoji statistički značajna razlika u mišljenju između STEM (znanost, tehnologija, inženjerstvo i matematika) i ne-STEM studenata o ovoj temi. Na temelju rezultata istraživanja mogu se predložiti dalinja istraživanja i integracija ove tehnologije u postavke visokog obrazovanja.

Ključne riječi: proširena stvarnost, augmentirani udžbenik, visoko obrazovanje, stavovi studenata

\section{(c) ()$_{\mathrm{BY}} \$$}

Međunarodna licenca / International License:

Imenovanje-Nekomercijalno / Attribution-NonCommercial 